Berkala Ilmu Perpustakaan dan Informasi, Vol. 16, No. 1, Juni 2020, Hal. 68-82 DOI: 10.22146/bip.v16i1.296

ISSN 1693-7740 (Print), ISSN 2477-0361 (Online)

Tersedia online di https://journal.ugm.ac.id/v3/BIP

\title{
Perkembangan publikasi internasional bidang pemantauan radiasi tahun 2011-2019 melalui basis data Scopus
}

\author{
Noeraida \\ Pusat Pendayagunaan Informatika dan Kawasan Strategis Nuklir \\ Badan Tenaga Nuklir Nasional \\ Kawasan Nuklir Serpong Tangerang Selatan 15310 \\ E-mail: noerda@batan.go.id
}

Naskah diterima: 13 Mei 2020, direvisi: 2 Juni 2020, disetujui: 14 Juni 2020

\begin{abstract}
ABSTRAK
Pendahuluan. Peneliti dan perekayasa membutuhkan data untuk memetakan kemajuan penelitian bidang pemantauan radiasi. Tujuan kajian untuk mengetahui perkembangan publikasi, peneliti, lembaga, negara, jurnal yang produktif dan banyak disitasi, pemetaan pengetahuan, kolaborasi peneliti, dan publikasi peneliti Indonesia. Metode penelitian. Analisis bibliometrik dengan pendekatan kuantitatif, populasi data dari Scopus tahun 20112019, pemetaan dengan VOSviewer.

Data analisis. Analisis dilakukan dengan tabulasi data menggunakan microsoft excel untuk menghasilkan peringkat sesuai dengan tujuan penelitian. Analisis pemetaan data bibliografi dilakukan untuk menghasilkan cooccurrence pada index keywords, dan co-authorship pada authors. Analisis deskriptif dilakukan untuk menjelaskan hasil.

Hasil dan Pembahasan. Jumlah publikasi dan yang mensitasi per tahun meningkat, memiliki rasio 1:6. Japan mendominasi pada peneliti yang produktif yaitu Onda Y, lembaga dan negara tertinggi yang disitasi. Jurnal tertinggi yang mempublikasikan pemantauan radiasi dan disitasi Journal of Environmental Radioactivity. Dokumen tertinggi yang menjadi rujukan ditulis oleh Halliburton dari USA. Pemetaan menghasilkan topik yang paling popular adalah reactor accidents, nuclear power plants dan radiation theraphy. Publikasi peneliti Indonesia yang terindeks di Scopus belum banyak.

Kesimpulan dan Saran: Japan memiliki publikasi paling berkembang, produktif dan popular baik peneliti, insitusi maupun negara serta menjadi rujukan para peneliti di dunia. Dapat dilakukan kajian menggunakan aplikasi lain dengan data dari pengindeks lain.
\end{abstract}

Kata kunci: pemantauan radiasi; bibliometrika; pemetaan pengetahuan

\section{ABSTRACT}

Introduction. There has been rapid development in radiation research. The purpose of the study is to understand the development of publications, researchers, institutions, countries, level of productivity and widely cited journals, knowledge mapping, researcher collaborations, and Indonesian researcher publications.

Data Collection Method. This paper used a bibliometric analysis with a quantitative approach, by using Scopus datafrom 2011 to 2019, mapped by VOSviewer.

Data Analysis. The analysis was performed by tabulating data using Microsoft Excel to produce rankings in accordance to the research objectives. Mapping analysis of bibliographic data was performed to provide cooccurrence of index keywords, and co-authorship of authors. Descriptive analysis was conducted to explain the results.

Results and Discussion. The number of publications and citations per year increases with ratio 1: 6. Japan as the highest institution and country cited, dominates productive researchers with Onda Y as one top researcher. The highest cited journal publishing radiation monitoring research is the Journal of Environmental Radioactivity. 
The highest referenced document is written by Halliburton from the USA. The most popular topics of discussion are reactor accidents, nuclear power plants and radiation therapy. There are not many publications by Indonesian researchers indexed on Scopus.

Conclusions. Japan has the most developed, productive and popular publications. Japanese researchers and institutions are widely used a reference globaly in the field of nuclear andradiation.

Keywords: radiation monitoring; bibliometrics; knowledge mapping

\section{A. PENDAHULUAN}

Badan Tenaga Nuklir Nasional (BATAN) merupakan satu-satunya lembaga penelitian, pengembangan dan perekayasan bidang iptek nuklir di Indonesia yang hasilnya ditujukan untuk maksud damai dan meningkatkan kesejahteraan rakyat Indonesia. Penggunaan teknik nuklir menggunakan unsur radioaktif, antara lain sinar alfa, beta, dan gamma. Pemanfaatan teknik nuklir sampai saat ini sudah memasuki hampir semua bidang kehidupan seperti bidang kedokteran, teknik perunutan, dan bidang pertanian. Litbangyasa pelaksanaannya, BATAN sebagai badan pelaksana pemanfaatan nuklir di Indonesia, bekerja sesuai dengan tugas yang tertuang dalam undang-undang dan diawasi secara ketat oleh Badan Pengawas Tenaga Nuklir (Bapeten) dan Badan Tenaga Atom Internasional (International Atomic Energy Agenc/IAEA). Pengawasan dan pemantauan penggunaan zat radioaktif sangat diperlukan untuk melindungi seluruh pekerja, masyarakat dan lingkungan hidup dari bahaya radiasi yang ditimbulkan.

Indonesia saat ini telah memiliki tiga Instalasi Nuklir beserta fasilitas pendukung yang terletak di Yogyakarta, Bandung dan Serpong yang dikelola oleh BATAN. Proteksi terhadap lingkungan menjadi hal utama yang diperhatikan untuk keselamatan instalasi tersebut. Oleh karena itu setiap instalasi sudah memiliki sistem pemantau yang berdiri sendiri. Untuk Kawasan Nuklir Serpong pemantauan radiasi sudah real time dan ditampilkan secara online di website Batan yang dikelola oleh Pusat Pendayagunaan Informatika dan Kawasan Strategis Nuklir (PPIKSN). Sistem ini memantau secara real time dan langsung ditampilkan dalam situs https://radmon.batan.go.id/m/d/xVnKIlOZz/ pemantauan-radiasi-dan-meteorologi-kns.
Karena teknologi nuklir merupakan teknologi yang memiliki resiko yang tinggi, maka selain faktor proteksi terhadap keselamatan lingkungan, faktor keamanan juga sangat penting untuk dipantau.

Sistem Pemantauan Radiasi untuk Keselamatan dan Keamanan (SPRKK) merupakan salah satu riset yang akan dibangun sistem informasi pemantauan radiasi skala nasional, prototip alat pengukur radiasi yang bersifat statis maupun mobile yang laik industri beserta kebijakan pendukungnya. Tujuan dari pembuatan SPRKK ini, menurut I. Putu Susila dari Pusat Rekayasaan Fasilitas Nuklir-BATAN (2019) adalah untuk peningkatan jumlah sarana pencegahan peredaran benda berbahaya terhadap pelaku kelompok kriminal dan teroris, peningkatan kualitas dan sarana pemantauan lalu lintas zar radioaktif di fasilitas publik, serta peningkatan penanganan dalam hal emergency preparedness (Pusat Rekayasaan Fasilitas Nuklir-BATAN, 2019).

Penugasan tersebut akan berjalan dengan baik bila didukung oleh sistem manajemen dan dukungan SDM yang handal, yang hasilnya dapat dirasakan manfaatnya oleh masyarakat serta berkontribusi untuk mewujudkan Indonesia yg berdaya saing dan sejahtera. Oleh karena itu, para peneliti dan perekayasa membutuhkan literatur dan publikasi ilmiah yang dapat memetakan kemajuan dan perkembangan pengetahuan bidang pemantauan radiasi atau radiation monitoring. Trend pengetahuan bidang pemantauan radiasi ini menurut Morant, et al. (2017) dapat ditelusuri, dan hasilnya dapat dijadikan sebagai acuan bagi para pelaku litbangyasa baik yang sudah senior maupun yang baru untuk menunjukkan literatur yang dapat dimasukkan dalam analisis penelitiaannya. Selain itu menurut Tupan (2016) dapat menjadi bahan 
evaluasi dalam melakukan penelitian, agar biaya dan alokasi dana yang besar dapat bermanfaat secara optimal. Para peneliti dan perekayasa di BATAN sebagai pelaksana yang akan mengembangkan sistem pemantauan radiasi untuk keselamatan dan keamanan, akan membutuhkan evaluasi hasil penelitian dan perkembangan publikasi ilmiah yang dapat memetakan kemajuan penelitian yang sudah dilakukan.

Hasil penelitian dan perkembangan pengetahuan tentang pemantauan radiasi atau "radiation monitoring" dalam publikasi internasional dapat ditelusuri salah satunya adalah melalui basis data Scopus. Menurut Lukman et al. (2019), sebagai lembaga pengindeks bereputasi tinggi Scopus merupakan salah satu basis data abstrak, pengindeksan, dan kutipan terbesar dari kepustakaan yang berasal dari proses ulasan mitra bestari (peer-review) yang ada di dunia. Penggunaan bibliometriks telah banyak dilakukan dan salah satu yang mendasari meningkatnya ketertarikan pada bidang ini adalah karena metode pengukuran ini dapat digunakan untuk melakukan evaluasi kinerja dan trend riset baik secara pribadi maupun perorangan. Namun kajian bibliometriks tentang pemantauan radiasi sampai saat ini belum dilakukan. Berdasarkan latar belakang tersebut maka kajian bibliometriks tentang perkembangan publikasi internasional bidang pemantauan radiasi dilakukan.

Tujuan dalam kajian ini adalah untuk mengetahui perkembangan publikasi internasional bidang pemantauan radiasi melalui basis data Scopus tahun 2011-2019. Adapun rumusan masalah dalam kajian ini adalah: (1) Bagaimana perkembangan publikasi internasional bidang pemantauan radiasi sejak tahun 2011-2019? (2) Siapa peneliti yang produktif dan paling banyak disitasi? (3) Apa saja jurnal internasional yang mempublikasikan artikel bidang pemantauan radiasi dan yang paling banyak disitasi; (4) Lembaga mana saja yang produktif melakukan penelitian pemantauan radiasi; (5) Negara mana yang produktif mempublikasikan artikel tentang pemantauan radiasi dan paling banyak dititasi; (6) bagaimana pemetaan pengetahuan bidang pemantauan radiasi. (7) dan bagaimana perkembangan publikasi dan penelitian dalam bidang pemantauan radiasi di Indonesia.

Ruang lingkup kajian adalah publikasi ilmiah hasil penelitian bidang pemantauan radiasi yang dipublikasikan pada jurnal yang terindeks di Scopus periode sejak 2011-2019. Melalui kajian ini diharapkan dapat menjadi rujukan mengenai perkembangan dan pemetaan pengetahuan bagi para pelaku litbangyasa dan masyarakat ilmiah yang akan melakukan penelitian dan yang berminat untuk mempelajari bidang pemantauan radiasi.

\section{B. TINJAUAN PUSTAKA}

Dalam glosarium yang diterbitkan oleh BATAN, pengertian radiasi adalah emisi dan propagasi energi melalui materi atau ruang dalam bentuk gelombang elektromagnetik atau partikel. Sedangkan radiation monitoring atau pemantauan radiasi adalah pengukuran kuantitas radiasi secara kontinu atau periodik (Badan Tenaga Nuklir Nasional, 2020). Setiap orang yang tinggal di dunia selalu menerima radiasi baik yang berasal dari sumber radiasi alamiah maupun sumber radiasi buatan. Radiasi yang dimaksud adalah radiasi pengion, yaitu radiasi yang dapat menimbulkan ionisasi, apabila radiasi tersebut menumbuk suatu bahan. Jika bahan tersebut manusia maka dapat mengakibatkan kerusakan jaringan pada manusia. Menurut Sutarman et al (2010), orang yang sering menerima radiasi, maka zat radioaktif dapat masuk ke dalam jaringan organ manusia melalui pernapasan, pencernaan, dan kulit. Selain itu, Istofa et al. (2015) menjelaskan bahwa penyebaran zat radioaktif ke lingkungan perlu dipantau dan diamati secara sungguhsungguh dan dilakukan baik di dalam maupun di luar instalasi yang kemungkinan dapat terkena paparan radiasi. Saat ini, BATAN sudah memiliki perangkat pemantau radiasi lingkungan Kawasan Nuklir Serpong (KNS) yang dikelola oleh Pusat Pendayagunaan Informatika dan Kawasan Strategis Nuklir (PPIKSN). Sistem ini memantau secara real 
time dan langsung ditampilkan dalam situs https://radmon.batan.go.id/m/d/xVnKIlOZz/ pemantauan-radiasi-dan-meteorologi-kns.

Penelitian dalam bidang pemantauan radiasi yang dihasilkan oleh para peneliti di dunia, dapat dilihat dari produktivitas para peneliti melalui publikasi ilmiah yang sudah diterbitkan dalam jurnal ilmiah. Produktivitas peneliti dapat diukur dari jumlah hasil penelitian yang dilakukan dan diterbitkan dalam publikasi ilmiah bereputasi antara lain terindeks pada scopus. Menurut Damayanti (2015) dalam Noeraida (2019), terkait kriteria produktivitas peneliti, jika mengacu pada Perka LIPI Nomor 2 Tahun 2014, maka kriteria capaian kerja peneliti yakni publikasi ilmiah, HAKI, serta kegiatan diseminasi. Menurut Lukman (2019), karena penelitian bersifat kompleks, untuk menilai kinerja hasil penelitian, seringkali diukur dengan output atau luaran berupa publikasi ilmiah, paten dan lainnya yang telah diterbitkan pada jurnal ilmiah internasional yang terindeks pada lembaga pengindeks yang bereputasi. Evaluasi penelitian untuk pengukuran kinerja semua peneliti ilmiah sebagian besar diperoleh dari kutipan dan alat analisis kutipan yang ada saat ini. Pendekatan atau metodologi yang paling banyak digunakan untuk pengelolaan kutipan menggunakan Scientometrics dan bibliometrics.

Scientometrics adalah studi tentang fitur dan karakteristik kuantitatif, penelitian ilmiah, dan komunikasi ilmiah. Untuk mengidentifikasi hasil penelitian yang telah dilakukan dalam bidang tertentu, menurut Admaja (2018) dapat dilakukan dengan mengeksplorasi kerangka literatur mendasar yaitu dengan pendekatan scientometrics terhadap jurnal yang telah terbit. Scientometrics terdiri dari beberapa subbidang seperti citation, co-authorship, co-word, cooccurrence, collaboration dan mapping science. Hayati (2018) menjelaskan analisis sitasi merupakan salah satu cabang bibliometrika yang membahas tentang sitiran atau kutipan pada sumber-sumber bacaan dari sebuah karya tulis ilmiah yang dipublikasikan dalam jurnal prosiding dan lainnya. Artikel yang terpublikasi secara internasional maupun nasional dan disitasi oleh penulis lain, mengindikasikan bahwa hasil-hasil penelitian tersebut telah sampai kepada masyarakat.

Menurut Pattah (2013), bibliometrika mempunyai tiga fungsi yaitu: (1) fungsi deskripsi, sarana untuk menyediakan sejumlah kegiatan penerbitan pada tingkat negara, propinsi, kota ataupun lembaga sebagai analisis produktivitas koparatif, (2) evaluasi, digunakan untuk menilai kinerja unit penelitian, dan (3) sebagai bagian dari prosedur standar untuk mengevaluasi dan memonitor ilmu pengetahuan dan teknologi. Selain itu, Saikia et all (2020) menjelaskan bahwa dalam studi bibliometriks, h-indeks dapat digunakan untuk menilai dampak penelitian oleh penulis, jurnal-jurnal dan negara-negara dalam bidang pengetahuan tertentu.

Terdapat beberapa sumber basis data online dari lembaga pengindeks bereputasi untuk kajian scientometrics seperti Web of Science, Scopus, dan sebagainya. Scopus merupakan database pengindeks internasional bereputasi tinggi yang berisi kumpulan ringkasan literatur terbesar di dunia, dengan citation (kutipan) yang menyediakan bibliografi artikel, abstrak berkualitas dari literatur-literatur ilmiah dan penelitian yang telah di-review (peer-reviewed) dan diterbitkan oleh lebih dari 5.000 penerbit di seluruh dunia serta mencakup berbagai bidang pengetahuan. Hasil export data dari basisdata scopus, dengan bantuan aplikasi bibliometrik tertentu dapat membuat pemetaan bidang pengetahuan tertentu. Sedangkan Hasil analisis bibliometrik menurut Tupan dan Rahmawati (2018) dapat divisualisasikan menggunakan beberapa aplikasi program seperti Bibexcel, Pajek, Gephi dan VOSviewer yang tersedia secara gratis dan dapat diunduh dari internet.

VOSviewer merupakan salah satu perangkat lunak yang dikembangkan oleh Eck dan Waltman (2018), dapat digunakan untuk memvisualisasikan peta bibliometriks publikasi ilmiah, penulis, jurnal, lembaga, dan kata kunci dan menafsirkan sebuah hubungan. Selain itu juga dapat mengeksplor peta pengetahuan melalui basis data yang diperoleh dari Web of science, Scopus, PubMed, RIS, CrossrefJSON 
dan CrossresAPI. Aplikasi ini dapat di unduh dan diinstal secara bebas dari situs resminya http://www.vosviewer.com.

Noeraida dan Iis Sustini (2018) terdapat 6 (enam) langkah dalam proses pemetaan pengetahuan yaitu: (1) melakukan seleksi terhadap obyek yang diminati, (2) melakukan perhitungan terhadap obyek yang saling berhubungan, (3) melakukan normalisasi dari nilai-nilai yang berhubungan, (4) merancang peta, (5) menyajikan peta dan (6) melakukan evaluasi terhadap peta. Menurut Tupan (2016), konsep ilmu pengetahuan yang terkandung dalam suatu dokumen dapat dilihat melalui katakata yang digunakan atau melalui analisis coword yang didasarkan pada analisis cooccurrence kata atau kata kunci dari dua atau lebih dokumen yang digunakan untuk mengindeks dokumen.

Analisis co-word menurut Tupan (2016) digunakan untuk menghitung jumlah kata kunci dari suatu dokumen penelitian yang muncul secara bersamaan pada dokumen yang diteliti, yang umumnya kata kunci tersebut dibuat oleh penulis. Semakin banyak kata kunci tertentu muncul dalam suatu dokumen yang menjadi fokus dalam kajian, semakin kuat hubungan antara dokumen-dokumen tersebut. Saikia, et al. (2020) juga menjelaskan bahwa analisis kata kunci merupakan metodologi bibliometriks untuk menganalisis konten dari kata kunci yang diekstraksi dan dihitung berdasarkan frekuensi kemunculan. Secara umum peneliti mengandalkan kata kunci dan judul publikasi sebagai poin penting untuk memantau kemajuan bidang penelitian tertentu. Untuk menganalisis kata kunci digunakan kata kunci yang ditentukan oleh penulis menggunakan VOSviewer karena lebih komperhensif untuk mewakili konten literatur.

Penelitian sebelumnya yang sudah dilakukan untuk mengetahui perkembangan pengetahuan bidang tertentu menggunakan aplikasi VOSviewer yakni Saikia, et al. (2020) dari Universitat Rovira i Virgili, Spain. Kajian yang dilakukan adalah analisis bibliometrik untuk mengetahui tren dalam bidang solar cooling technology menggunakan VOSviewer, bibliometrika paket $\mathrm{R}$ dan bibliometriks internal. Pemetaan menggunakan kata kunci dari authors indexs, dan hasil analisis diperoleh solar cooling technologie merupakan topik yang paling banyak diteliti dalam 50 tahun terakhir. Morant, et al. (2017) dari Universidad de Sevilla, Spain juga melakukan kajian analisis bibliometriks dan pemetaan bidang inovasi hijau menggunakan Bibexcel untuk analisis data dan untuk visualisasi menggunakan Pajek. Sedangkan Royani et al. (2019) dari LIPI melakukan kajian tentang visualisasi bibliometrik bidang ilmu kegempaan di Indonesia dengan mengambil basis data dari scopus, juga menggunakan VOSviewer. Hasil kajian menunjukkan topik bidang ilmu kegempaan di Indonesia yang paling banyak diteliti yakni Earth and Planetary Sciences. Tupan dan Rachmawati (2018) dari LIPI juga melakukan analisis bibliometrik bidang ilmu dan teknologi pangan dari publikasi ilmiah di negara-negara ASEAN. Data diambil dari scopus, analisis data menggunakan microsoft excel, visualisasi pengetahuan menggunakan VOSviewer. Hasil kajian adalah pertumbuhan publikasi ilmiah ilmu dan teknologi pangan meningkat. Subjek yang paling banyak dikaji adalah agriculturel and biological sciences. Selanjutnya Awangga (2018) dari KOMINFO melakukan kajian Pemetaan riset teknologi 5G yang juga menggunakan VOSviewer. Hasil yang diperoleh melalui pengolahan kata kunci, Massive MIMO merupakan topik yang paling banyak dipilih dan dilakukan dalam penelitian.

\section{METODOLOGI PENELITIAN}

Kajian ini dilakukan menggunakan metode analisis bibliometrik dengan basis data online Scopus. Untuk memetakan trend penelitian, menggunakan aplikasi bibliometrik VOSviewer versi 1.6.8. Kajian mulai dilakukan pada tanggal 27 Februari 2020, dan analisis kajian dilakukan sampai dengan bulan 23 Maret 2020. Penyajian data menggunakan tabel (tabulasi) sesuai dengan tujuan kajian untuk menjelaskan hasildapat dilihata pada Gambar 1. 


\section{HASILDAN PEMBAHASAN \\ Perkembangan penelitian pemantauan radiasi di dunia}

Perkembangan

penelitian

\section{bidang}

bidang pemantauan radiasi di dunia pada basisdata Scopus tahun 2011-2019 diperoleh sebanyak 2.469 judul. Tipe dokumen terdiri dari artikel sebanyak 2.236 judul atau 90,56\%, review 100 judul atau 4,05\%, conference paper 58 judul atau 2,35\% dan lainnya 74 judul atau 3,04\%. Pertumbuhan publikasi pada tahun 2011 sebesar 153 judul atau $6,2 \%$, mengalami peningkatan pada tahun 2016 dan 2017 sebanyak 359 judul atau sebesar $14,54 \%$, namun menurun kembali pada tahun 2018 dan 2019. Secara umum, jumlah publikasi peneliti di bidang pemantauan radiasi di dunia meningkat dengan rata-rata 274 publikasi per tahun, meskipun mengalami penurunan pada tahun 2018 dan 2019. Oleh karena itu sejalan dengan pendapat Lukman, et al. (2019) bahwa perlu dilakukan evaluasi untuk mengetahui kualitas hasil penelitian, kekuatan, dan kelemahan dalam produktivitas, reputasi dan dampak peneliti atau institusi ilmiah.

Namun jumlah peneliti yang mensitasi artikel bidang pemantauan radiasi diperoleh sebanyak 14.872 kali. Peningkatan yang signifikan terutama pada tiga tahun terakhir yaitu pada tahun 2017 sebesar 2.477 kali atau $16,66 \%$, tahun 2018 sebanyak 3.064 kali atau 20,60\%, dan paling banyak pada tahun 2019 yaitu sebesar 3.293 kali atau $22,14 \%$. Perbandingan jumlah publikasi dengan jumlah artikel yang mensitasi diperoleh rasio 2.495:14.872 = 1:6 seperti dapat dilihat pada Tabel Gambar 2. Hasil ini menunjukkan bahwa artikel yang telah terpublikasi pada jurnal internasional dan banyak disitasi oleh penulis lain mengindikasikan hasil-hasil penelitian tersebut memiliki dampak yang positif, diminati dan telah sampai kepada masyarakat. Selain itu, penelitian dalam bidang pemantauan radiasi menarik minat para peneliti untuk melakukan kajian.

\section{Produktivitas peneliti}

Berdasarkan hasil analisis dari scopus, dari 2.469 judul publikasi merupakan hasil penelitian dari 434 peneliti yang memiliki artikel minimal 1 judul. Diperoleh 10 peringkat peneliti bidang pemantauan radiasi yang memiliki minimal 15 artikel seperti pada Tabel 1. Peneliti yang paling produktif adalah Onda Y. dari University of Tsukuba, Japan sebanyak 35 judul dan memiliki dengan h-index 37, Beresford N.A. dari University of Salford, United Kingdom 23 judul dengan h-index 34, dan Povinec, P.P. dari Comenius University, Bratislava, Slovakia sebanyak 20 judul dengan h-index paling tinggi 43.

Peneliti yang paling banyak disitasi dengan kriteria memiliki minimal 5 dokumen dan disitasi minimal 100 kali, diperoleh 84 penulis. Peneliti tertinggi yaitu Onda Y. yang disitasi sebanyak 1.140 kali dengan judul artikel Depth Distribution of ${ }^{137} \mathrm{Cs},{ }^{134} \mathrm{Cs}$, and ${ }^{131}$ I in soil profile after Fukushima Dai-ichi Nuclear Power Plant Accident. Hirose, K. dari Sophia University, Tokyo, Japan disitasi sebanyak 536 kali dengan judul artikel Distribution of oceanic ${ }^{137} \mathrm{Cs}$ from the Fukushima Dai-ichi Nuclear Power Plant simulated numerically by a regional ocean model. Tragedi bocornya reaktor nuklir di Fukushima, Jepang disebabkan oleh gempa yang terjadi pada Senin 5 Desember 2011 membuat para peneliti di Jepang melakukan penelitian dan evaluasi terhadap sebab terjadinya peristiwa tersebut.

\section{Jurnal internasional yang mempulikasikan artikel bidang pemantauan radiasi}

Jumlah jurnal yang paling banyak mempublikasikan artikel bidang pemantauan radiasi ditemukan sebanyak 160 judul. Jurnal yang paling banyak mempublikasikan adalah Journal of Environmental Radioactivity sebanyak 1.547 kali, Journal of Radiological Protection 163 kali, dan Journal of radioanalytical and nuclear chemistry 118 kali. Journal of Environmental Radioactivity merupakan jurnal yang paling relevan dengan pemantauan radiasi dan banyak disitasi sejak tahun 2011-2019. Untuk membandingkan jurnal yang paling baik dan relevan, digunakan beberapa indikator yaitu jumlah peneliti yang mensitasi, h-index jurnal dan klusterisasi jurnal berdasarkan kualitas dengan istilah Quartile 
(Q), yang dikelompokkan oleh SJR (SCIMAGO Journal and Country Rank) untuk melihat Impact Factor (IF) sebuah jurnal. Jurnal yang paling banyak disitasi adalah Journal of environmental radioactivity yang diterbitkan oleh Elsevier Netherland dengan H-Index 80, termasuk dalam kluster Q1 yaitu jurnal yang paling utama dari sisi kulitas, disusul oleh Journal of radiological protection H-Index 39 termasuk dalam kluster Q2.

Journal of environmental radioactivity merupakan jurnal internasional berkualitas, paling relevan, dan paling banyak disitasi. Hal ini dapat dilihat dari ruang lingkup selain untuk pemantauan radioaktivitas lautan, sungai, atmosfir, dan semua divisi biosfer, eksperimental dan teoritis, juga termasuk pemodelan, geofisika, radioaktivitas lingkungan, pemantauan dalam pembuangan limbah dan lainnya. Informasi lengkap dapat dilihat pada website jurnal https://www.sciencedirect.com/journal/journalof-environmental-radioactivity/about/aimsand-scope. Selain itu, untuk mengukur dampak penelitian oleh sumber publikasi, penulis, lembaga, atau negara, faktor dampak dan hindeks merupakan sebuah indikator untuk menentukan artikel yang akan dijadikan rujukan dalam penelitian.

\section{Produktivitas lembaga yang mempublikasikan artikel bidang pemantauan radiasi}

Lembaga atau institusi yang paling produktif melakukan penelitian bidang pemantauan radiasi adalah sebanyak 160 lembaga. Lembaga atau institusi yang paling banyak publikasinya adalah Japan Atomic Energy Agency, Japan sebanyak 81 judul, University of Tokyo, Japan 55 artikel, dan paling sedikit adalah Bhabha Atomic Research Centre 42 judul. Sedangkan institusi yang paling banyak disitasi dengan kriteria minimum 5 dokumen dan disitasi minimal $25 \mathrm{kali}$, diperoleh 10 peringkat institusi. Peringkat pertama adalah Center for Research in Isotopes and Environmental Dynamics, University of Tsukuba, Japan disitasi sebanyak 356 kali, diikuti oleh International Atomic Energy
Agency (IAEA), Austria sebanyak 293 kali, dan paling sedikit adalah Institute of Radiochemistry and Radioecology, University of Pannonia, Hungary sebanyak 41 kali. Nama lembaga atau institusi bermanfaat selain untuk kepentingan penulis dalam berkolaborasi, juga dalam eksperimen laboratorium dan mengamati globalisasi penelitian imliah.

\section{Produktivitas negara yang mempublikasikan artikel bidang pemantauan radiasi}

Negara yang paling produktif diperoleh 119 negara, dan diperoleh 10 peringkat tertinggi Japan dengan jumlah publikasi sebanyak 408, diikuti United States 402, yang paling kecil adalah Russian Federation 99 judul. Indonesia termasuk dalam peringkat ke 64 dengan jumlah publikasi 5 judul. Sedangkan negara yang paling banyak disitasi dengan kriteria minimal memiliki 5 artikel dan disitasi minimal 100 kali, diperoleh 47 negara. Sedangkan 10 peringkat negara yang paling banyak disitasi adalah Japan disitasi sebanyak 6.848 kali, diikuti oleh Unites States 3.700 kali dan yang paling sedikit adalah Russian Federation 942 kali. Indonesia sampai saat berada pada posisi memiliki 3 judul artikel dan disitasi sebanyak 13 kali.

Selanjutnya, dengan menggunakan VOSviewer dapat dilihat jaringan kolaborasi 47 negara tertinggi dalam penelitian bidang pemantauan radiasi dan saling mensitasi melalui publikasinya, dan diperoleh 5 kluster. Jepang memiliki kolaborasi yang paling kuat berkolaborasi dengan Amerika dan Inggris, Austria dan Russian serta German. Indonesia berada pada kluster 1 yang berkolaborasi dengan Austria, Egypt, India, dan lainnya. Kolaborasi riset antar negara yang kuat akan meningkatkan daya saing serta promosi di dunia internasional.

\section{Pemetaan pengetahuan berdasarkan index keywords}

Untuk mengetahui trend penelitian dipetakan menggunakan aplikasi VOSviewer berdasarkan kata kunci pada index keywords yang paling popular atau sering muncul (cooccurrence). Menurut Saikia, et al. (2020) kata 
kunci dapat mewakili ide utama dalam penelitian. Untuk pemetaan VOSviewer dengan filter jumlah kata kunci yang sering muncul ( $\mathrm{co}$ occurrence) pada index keywords diperoleh 16.957 kata kunci, yang memenuhi persyaratan hanya 2.748, dan dilakukan seleksi hanya kata kunci yang relevan yang dipilih. Pilihan yang muncul minimal 75 kali muncul, 164 keywords yang terkelompok pada 5 kluster besar yang ditunjukkan pada Gambar 3. Bulatan paling besar menunjukkan kata kunci tersebut paling banyak muncul, semakin kecil menunjukkan belum banyak dilakukan penelitian.

Pada kluster pertama yang ditunjukkan dengan warna merah terdiri dari 36 kata kunci dan radon paling banyak muncul 537 kali, yang berdekatan dengan air pollutants 462, atmospherics 397. Kata kunci yang letak bulatannya berjauhan artinya penelitian bidang radiation monitoring yang berkaitan dengan simulation 96 kali, meteorology 76, computer simulation 75 masih sedikit. Kluster kedua warna hijau terdiri dari 36 kata kunci, dan yang paling dominan adalah reactor accidents yang muncul 1.224 kali, cesium radioisotopes 1.111, nuclear power plants 870. Sedangkan yang masih sedikit penelitian yang berkaitan dengan iodine 131 dan fishes 79 kali. Kluster ketiga warna biru terdiri dari 34 kata kunci, yang paling banyak adalah penggunaan radioisotopes 1.196 kali, radioactivity 672 , spectroscopy 657 , dan gamma radiation 558 , dan penelitian yang berkaitan dengan radiation detector 79 monte carlo method 75 masih sedikit. Kluster keempat warna kuning terdiri dari 30 kata kunci dan yang paling banyak selain radiation monitoring yang muncul 2.363 kali, radiation dose 556, humans 541, radiation exposure 457, pollutants 379 , radiation protection 280, risk assessment 215 , dan yang paling sedikit adalah radiology 90, radiation injuries 83 . Kluster kelima yang ditunjukan dengan warna ungu terdiri dari 28 kata kunci, dan yang paling banyak muncul chemistry 465 kali, fallouts 379, radioactive wastes 372, sediments 345 , sedangkan yang paling sedikit adalah yang berkaitan dengan pollutants dan surface water 79, plutonium 239 dan plutonium $240 \quad 78$ kali dan spatial distribution 75 kali.
Selanjutnya kata kunci yang memiliki konsep yang sama diseleksi dan digabungkan dengan menggunakan panduan thesaurus INIS, misalnya cesium dan cesium isotopes ditulis sebagai cesium isotopes, gamma spectrometry menjadi spectroscopy dan lainnya. Hasilnya diperoleh sebanyak 121 kata kunci, dan peringkat 25 kata kunci yang paling sering muncul ditampilkan pada Gambar 4. Kata kunci yang sering muncul menunjukkan kecenderungan penelitian yang berkaitan dengan bidang pemantauan radiasi yang telah dilakukan. Topik yang berkaitan dengan radiation monitoring pada reactor accidents yang muncul 1.224 kali, radioisotopes 1.196 kali dan cesium isotopes 1.111 kali. Sedangkan kata kunci yang paling sedikti kemunculannya dan tidak termasuk dalam peringkat 25 adalah simulation 96 muncul sebanyak 96 kali, meteorology 76 , monte carlo methods 75 kali.

\section{Pemetaan berdasarkan kolaborasi peneliti}

Pemetaan co-authorship dilakukan untuk mengetahui jaringan kolaborasi antar penulis dan mengetahui peneliti yang paling popular dalam bidang pemantauan radiasi. Berdasarkan hasil pencarian dengan pilihan jumlah minimum 10 dokumen dan jumlah sitasi penulis minimum 100 kali, diperoleh 22 penulis yang terkoneksi menjadi 5 kluster dengan kode warna merah, hijau, biru, kuning dan ungu seperti pada Gambar 5. Pada kelompok atau kluster pertama berwarna merah terdiri dari 8 penulis, dan yang paling dominan adalah Beresford yang berkolaborasi dengan Bollhöfer, Doering, Fesenko, Salbu, Johansen, Vivies dan Wood. Para penulis kelompok merah melakukan penelitian yang berkaitan dengan radon, cesium 137 , radiation monitoring. Kelompok kedua berwarna hijau terdiri dari 4 penulis yaitu Provinec, Aoyama, Yamada dan Takashi dengan topik penelitian yang berkaitan dengan radionuclides, global fallouts dan seawater. Kelompok biru terdiri dari 4 penulis yang didominasi oleh Onda Y., Saito, Kato, dan Sanada, dengan topik yang berkaitan dengan radiocesium, Cesium 137 dan Fukushima. Kelompok kuning atau kluster 4 terdiri dari 4 
penulis yaitu Kitamura, Yoshimura, Nanba dan Konopley dan topik yang berkaitan dengan cesium, rivers dan fukushima nuclear accident. Kluster 5 dengan warna ungu hanya terdiri dari 2 penulis yaitu Yamamoto dan Inoue dengan topik penelitian yang berkaitan dengan soils, cesium 137 dan fukushima nuclear accident. Peneliti yang paling popular adalah Onda Y. yang memiliki dokumen paling banyak 35 judul. Semakin tebal garisnya semakin kuat kolaborasi yang dilakukan. Hasil penelitian ini sejalan dengan pendapat Royani (2019) bahwa peneliti memiliki kecenderungan melakukan kolaborasi dengan beberapa penulis.

\section{Dokumen yang paling banyak disitasi}

Untuk mengetahui dokumen yang paling banyak disitasi, dilakukan menggunakan aplikasi VOSviewer dengan pilihan citation document diperoleh 2.472 dokumen. Dengan pilihan minimal disitasi 100 kali, diperoleh 17 dokumen, dan terkelompok menjadi 14 kluster. Dari 17 dokumen tersebut, 12 dokumen berkaitan dengan nuclear power plant accident fukushima, 5 judul lainnya berkaitan dengan kedokteran nuklir seperti radiation therapy dan tomography. Sedangkan yang paling banyak disitasi sebanyak 318 kali adalah dokumen yang ditulis oleh Halliburton S.S., et.al (2011) pada Journal of cardiovascular computed tomography pada tahun 2011 yang membahas tentang SCCT guidelines on radiation dose and dose-optimization strategies in cardiovascular CT. Selain itu Tsumune yang disitasi 227 kali pada tahun 2012 dengan judul Distribution of oceanic ${ }^{137} \mathrm{Cs}$ from the Fukushima Dai-ichi Nuclear Power Plant simulated numerically by a regional ocean model, yang dipublikasikan pada jurnal Journal of Environmental Radioactivity. Seluruh dokumen hasil pemetaan tersebut dapat dijadikan acuan oleh para peneliti sesuai dengan minat yang akan diteliti. Selain itu, judul-judul jurnal tersebut dapat menjadi bahan bagi pustakawan untuk mengusulkan berlangganan.

\section{Publikasi peneliti Indonesia dalam bidang pemantauan radiasi}

Ditemukan sebanyak 15 judul publikasi sejak tahun 1971-2020, namun sebanyak 1 judul artikel bukan nama peneliti BATAN, sehingga total menjadi 14 judul sejak tahun 1990-2020. Hasil penelitian paling banyak dipublikasikan tahun 2015. Hal ini menunjukkan bahwa di Indonesia belum banyak peneliti yang melakukan penelitian dalam bidang pemantauan radiasi yang hasilnya dipublikasikan pada jurnal internasional yang terindeks di scopus. Publikasi terbaru tahun 2020 ditulis oleh peneliti Muhtadan dari STTNBATAN yang berkolaborasi dengan peneliti dari PSTA Susilo Widodo. Sedangkan peneliti BATAN yang paling banyak artikelnya yakni Heny Suseno dari PTKMR yang melakukan penelitian tahun 2014, 2015 dan 2018. Dari 14 judul artikel tersebut, sebanyak 7 judul penelitian dlakukan oleh peneliti BATAN sebagai penulis pertama, 7 judul lagi berkolaborasi dengan instansi dari luar BATAN baik dalam maupun luar negeri.

Nama publikasi internasional yang menerbitkan artikel peneliti Indonesia di scopus adalah Marine Pollution Bulletin 3 artikel yang ditulis oleh Heny Suseno, merupakan jurnal bereputasi karena memiliki h-indeks 147 dengan termasuk dalam kluster 1 dengan SJR Q1. Minimnya peneliti Indonesia dapat disebabkan oleh 2(dua) hal yaitu penelitian dalam bidang pemantauan radiasi belum sebanyak di negara lain. Salah satu sebabnya antara lain penerapan teknologi nuklir dalam bidang energi belum dilakukan, banyak artikel hasil penelitian yang diterbitkan pada jurnal yang tidak ada di Scopus, atau dalam bahasa Indonesia yang sebagian besar terindeks di Google Scholar. Dengan jumlah penelitian yang masih minim, sangat tepat bila BATAN pada Renstra periode 2020-2024 melakukan penelitian dan inovasi dalam bidang pemantauan radiasi. Penelitian yang akan memberikan manfaat lingkup nasional untuk keselamatan radiasi publik dengan mengetahui distribusi zat radioaktif di lingkungan jika terjadi kecelakaan nuklir baik yang berasal dari dalam negeri maupun dari mancanegara. 
Berdasarkan hasil kajian ini menunjukkan bahwa topik pemantauan radiasi yang berkaitan dengan nuclear accident, radiosisopes, cesium dan nuclear power plants mendominasi topik penelitian dalam 9 (sembilan) tahun terakhir. Kecelakaan di Fukushima memberikan pengalaman dan memunculkan penelitian dan pengetahuan baru bagi para peneliti di Japan, sehingga menjadi negara yang paling produktif dan popular baik peneliti, insitusi maupun negara serta menjadi rujukan bagi peneliti lain di dunia. Selain itu, Saikia, et.al, 2020 menjelaskan bahwa h-indeks dapat digunakan untuk menilai dampak penelitian oleh penulis, jurnal-jurnal dan negara-negara dalam bidang pengetahuan tertentu.

Studi bibliometrik merupakan bagian dari ilmu statistik, dan saat ini banyak aplikasi yang dapat dengan mudah melakukan kajian bibliometrik yang salah satunya adalah aplikasi VOSviewer. Menurut Xie, et al. (2020), yang melakukan analisis Bibliometric and Visualized Analysis of Scientific Publications on Atlantoaxial Spine Q1 Q7 Q8 Surgery Based on Web of Science and VOSviewer memberikan pendapat bahwa, meskipun analisis data penelitian ini adalah relatif komprehensif dan objektif namun punya beberapa keterbatasan. Ada perbedaan antara hasil analisis bibliometrik dan kondisi penelitian nyata. Beberapa artikel berkualitas tinggi yang baru-baru ini diterbitkan tidak difokuskan karena frekuensi rujukannya yang rendah. Selain itu, ini merupakan studi cross sectional. Jika pencarian telah dilakukan pada waktu yang berbeda, jumlah kutipan dalam literatur bisa berbeda. Dengan demikian, studi yang baru-baru ini diterbitkan akan mengubah peringkat artikel, yang akan mengharuskan pembaruan studi di masa depan.

Hasil kajian ini diharapkan dapat menjadi bahan evaluasi terhadap rencana penelitian dan kegiatan BATAN dalam melakukan inovasi dengan mengembangkan sistem pemantauan radiasi untuk keselamatan dan keamanan secara nasional, agar dapat memberikan manfaat positif bagi masyarakat luas.

\section{E. KESIMPULAN}

Berdasarkan kajian yang sudah dilakukan, dapat disimpulkan bahwa jumlah publikasi internasional bidang pemantauan radiasi di dunia dalam sembilan tahun terakhir melalui basis data scopus mengalami peningkatan dengan rata-rata per tahun 274 judul. Perbandingan jumlah publikasi dengan jumlah artikel yang mensitasi di bidang pemantauan radiasi adalah 1:6 memiliki dampak yang positif. Japan mendominasi dalam produktifitas peneliti, lembaga dan negara yang paling produktif serta dan paling banyak disitasi atau menjadi rujukan di dunia dalam penelitian di bidang pemantauan radiasi. Peneliti yang paling popular adalah Onda Y dari Japan, dan dokumen yang paling banyak disitasi adalah Halliburton dari Cleveland State University USA. Jurnal yang paling banyak mempublikasikan penelitian di bidang pemantauan radiasi sekaligus paling banyak disitasi yaitu Journal of Environmental Radioactivity. Jumlah publikasi peneliti Indonesia dalam bidang pemantauan radiasi yang dipublikasikan pada jurnal internasional yang terindeks di scopus belum banyak, telah memiliki kolaborasi dengan peneliti dengan institusi lain baik dari dalam maupun luar negeri. Penelitian pada pemetaan pengetahuan melalui index keywords, ditemukan lima kata kunci yang paling berkaitan dengan pemantauan radiasi yakni reactor accidents, radioisotopes, cesium isotopes, nuclear power plants dan radioactivity. Diharapkan, kajian pemetaan ini bermanfaat dan dapat menjadi salah satu layanan pustakawan kepada pelaku litbangyasa di BATAN, agar memperoleh informasi, literatur dan hasil evaluasi tentang pengetahuan bidang tertentu, yang sudah dilakukan dan sedang berkembang di dunia sejak membuat proposal penelitian.

\section{UCAPAN TERIMA KASIH}

Kesempatan ini diucapkan terima kasih kepada kepala Subbidang Manajemen Pengetahuan Nuklir (MNP) Ibu Iis Sustini, A.Md. yang telah memberikan ijin dan dukungan untuk melakukan kajian ini. Terima kasih disampaikan juga kepada Perpustakaan 
Fakultas Teknik UGM dan pustakawan Bapak Purwoko, MA sebagai narasumber pada Workshop VOSviewer melalui unggahan videonya di channel youtube https://bit.ly/2YleZKD yang menjadi materi pembelajaran bagi penulis.

\section{DAFTAR PUSTAKA}

Admaja, A.F.S. (2018). Pemetaan riset teknologi 5G. Buletin Pos dan Telekomunikasi 16(1), 27-40. https://online.bpostel.com/index.php/bpost el/article/view/160103/317

Badan Tenaga Nuklir Nasional. 2019. Tahun 2020-2024 Badan Tenaga Nuklir Nasional akan jalankan 3 program prioritas riset nasional. Diakses 2 Maret 2020 dari http://www.batan.go.id/index.php/id/kede putian/manajemen/hhk/6150-tahun-20202024-batan-akan-jalankan-3-programprioritas-riset-nasional

Badan Tenaga Nuklir Nasional. 2020. Glosarium ilmu dan teknologi nuklir versi online. Diakses 11 Maret 2020 dari http://www.batan.go.id/index.php/id/ glosarium2

Eck, N. J. V. and Waltman, L. 2018. VOSviewer manual version 1.6.8. Diakses 27 Februari 2020 dari https:/www.vosviewer.com/ documentation/Manual_VOSviewer_1.6.8 .pdf

Hayati, N. (2018). Analisis sitiran sebagai alat evaluasi koleksi perpustakaan. Record and Library Journal 2(1), 1-15. http://dx.doi.org/10.20473/rlj.V2-I1.2016. $1-15$

Istofa, Yuniarsari, L., dan Susila, I.P. (2015). Perekayasaan perangkat pemantau radiasi lingkungan instalasi nuklir. Prima 12(1) 18. http://jurnal.batan.go.id/index.php/ prima/article/view/3842

Kementrian Riset, Teknologi dan Pendidikan Tinggi Republik Indonesia. 2019. Peraturan Menteri Riset, Teknologi, dan Pendidikan Tinggi Republik Indonesia nomor 38 tahun 2019 tentang Prioritas Riset Nasional Tahun 2020-2024.
Lukman, Hidayat, D.S., Al-Hakim, S., \& Nadhiroh, I.M. (2019). Pengukuran kinerja riset: Teori dan implementasi. Jakarta: LIPI Press.

Morant, G.A., Henseler, J., Leal-Millán. A. \& Cepeda-Carrión, G. (2017). Mapping the field: A bibliometric analysis of green innovation. Journal Sustainability 9(6) 115. https://doi.org/10.3390/su9061011

Noeraida. (2019). Produktivitas dan literasi peneliti Badan Tenaga Nuklir Nasional dalam menulis karya tulis ilmiah. Jurnal Perpustakaan Pertanian 28(1), 7-15.

Noeraida dan Sustini, I. (2018). Pemetaan pengetahuan bidang nuklir melalui karya tulis ilmiah peneliti BATAN yang terindeks di Scopus. Makalah dipresentasikan pada Prosiding Seminar Nasional SDM Teknologi Nuklir yang diselenggarakan di Yogyakarta pada tanggal 20 Agustus 2018. http://repo-nkm.batan.go.id/5998/

Noeraida. (2020). Laporan kajian analisis perkembangan publikasi internasional bidang pemantauan radiasi tahun 20112019 melalui basis data Scopus. PPIKSNBATAN, Serpong.

Pattah, S.H. (2013). Pemanfaatan kajian bibliometrika sebagai metode evaluasi dan kajian dalam Ilmu Perpustakaan dan Informasi. Khizanah Al-Hikmah Jurnal Ilmu Perpustakaan, Informasi dan Kearsipan 1(1) 47-57.

Pusat Rekayasan Fasilitas Nuklir, Badan Tenaga Nuklir Nasional. (2019). Riset pusat rekayasa fasilitas nuklir masuk dalam prioritas riset nasional. Diakses tanggal 2 Maret 2020 dari http://www.batan.go.id/ index.php/id/kedeputian/pendayagunaanteknologi-nuklir/rekayasa-fasilitasnuklir/6246-riset-pusat-rekayasa-fasilitasnuklir-masuk-dalam-prioritas-risetnasional

Royani, Y., Tupan \& Kusumaningrum, D. (2019). Visualisasi bibliometrik penelitian bidang ilmu kegempaan di Indonesia berbasis data scopus tahun 1988-2018. Khizanah al-Hikmah: Jurnal Ilmu Perpustakaan, Informasi, dan Kearsipan 7(2) 174-188. 
Saikia, K., Vallès, M. Fabregat. A., Saez, R. \& Boer, D. (2020). A bibliometric analysis of trends in solar cooling technology. Solar Energy 199(15) 100-114. Diakses 20 Maret 2020 dari https://doi.org/10.1016/ j.solener.2020.02.013

Sutarman, Syarbaini, Kusdiana, dan Setiawan, A. (2010). Pemantauan lingkungan untuk keselamatan radiasi publik di Indonesia. Makalah dipresentasikan pada Seminar Nasional Keselamatan Kesehatan dan Lingkungan VI di Jakarta pada tanggal 1516 Juni 2010. Diakses 23 Maret 2020 dari http://digilib.batan.go.id/ppin/katalog/file/ sutarman.pdf

Tupan. (2016). Peta perkembangan penelitian pemanfaatan repository institusi menuju open access: studi bibliometrik dengan VOSViewer. Khizanah Al Hikmah Jurnal Ilmu Perpustakaan, Informasi dan Kearsipan, 4(2) 104-117.
Tupan dan Rachmawati, R. (2018). Analisis bibliometrik ilmu dan teknologi pangan: publikasi ilmiah di negara-negara ASEAN. Khizanah Al Hikmah Jurnal Ilmu Perpustakaan, Informasi dan Kearsipan, 6(1) 26-40.

Xie, L., Chen, Z., Wang, H., Zheng, C., Jiang, J. (2020). Bibliometric and visualized analysis of scientific publications on atlantoaxial spine Q1 Q7 Q8 surgery based on web of science and vosviewer. World Neurosurgery 137, 435-442. 


\section{DAFTAR GAMBAR}

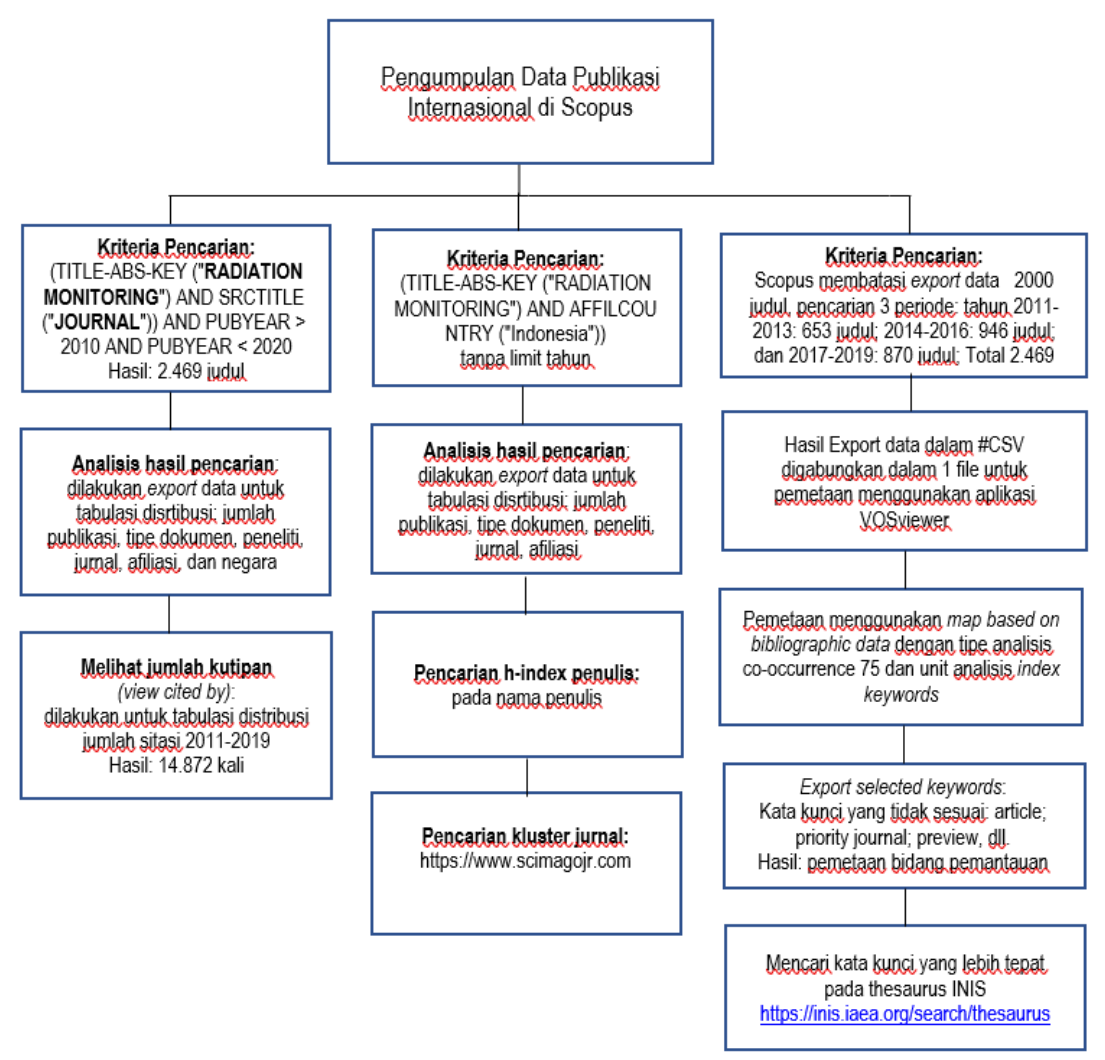

Gambar 1. Diagram Pengumpulan Data

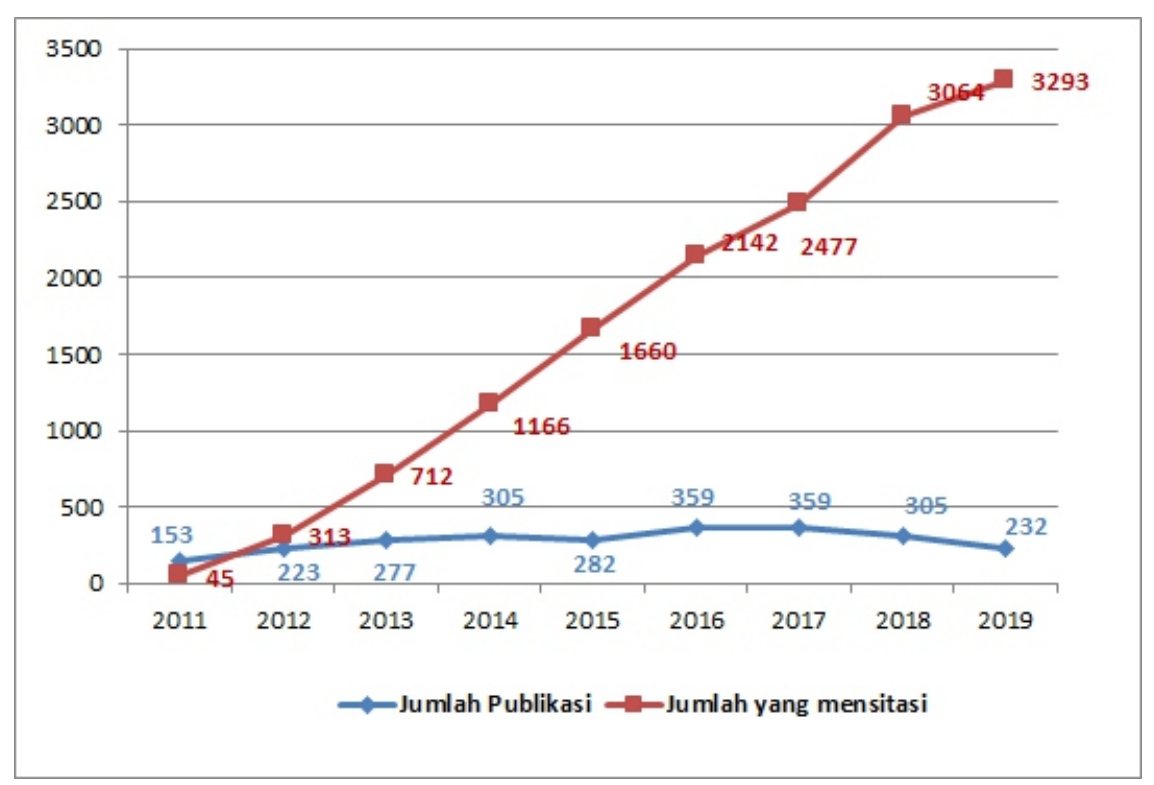

Gambar 2. Perbandingan jumlah publikasi bidang pemantauan radiasi dengan artikel yang mensitasi pada scopus Tahun 2011-2019 


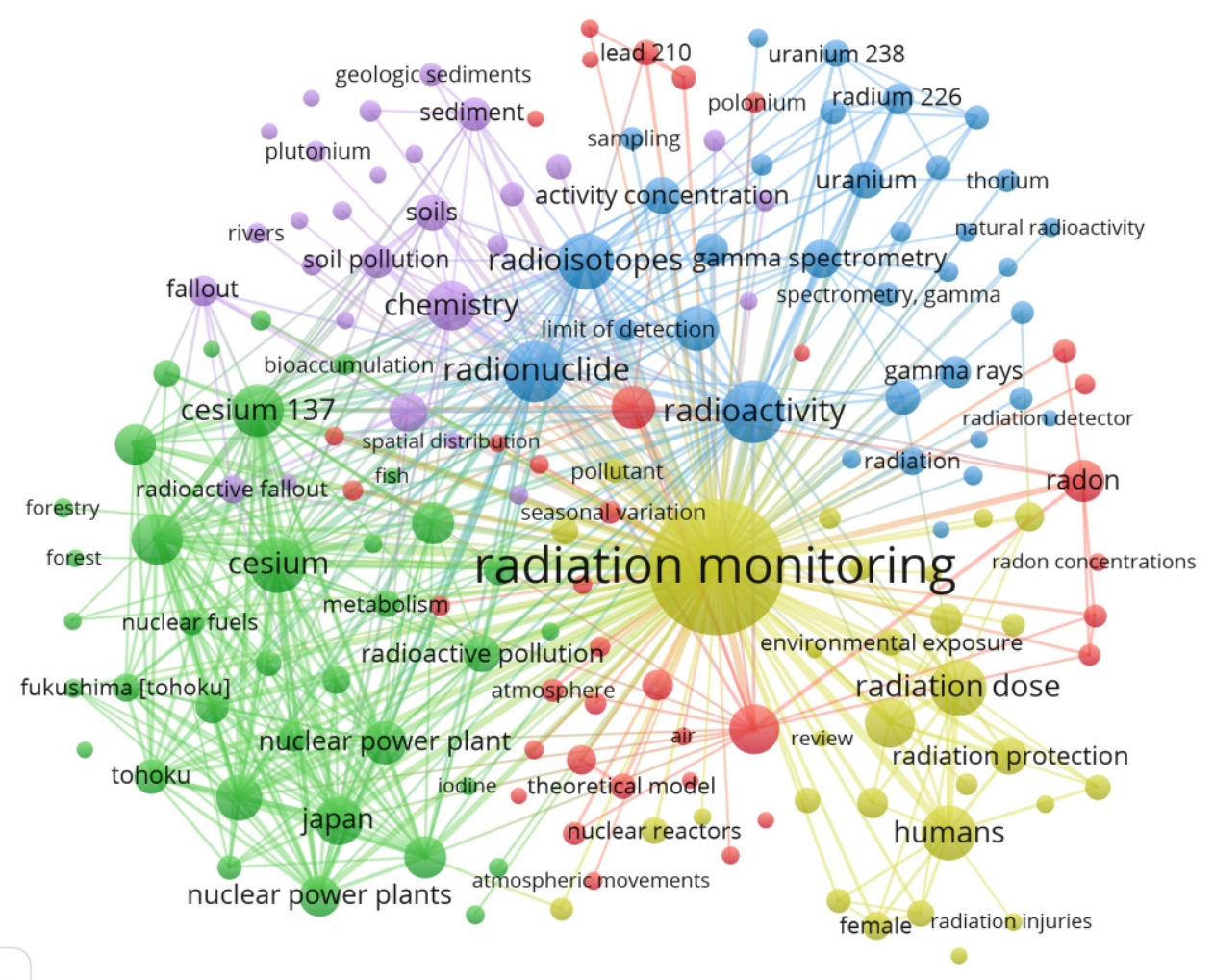

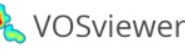

Gambar 3. Pemetaan bidang pemantauan radiasi melalui index keywords dengan co-occurrence minimum 75 kali

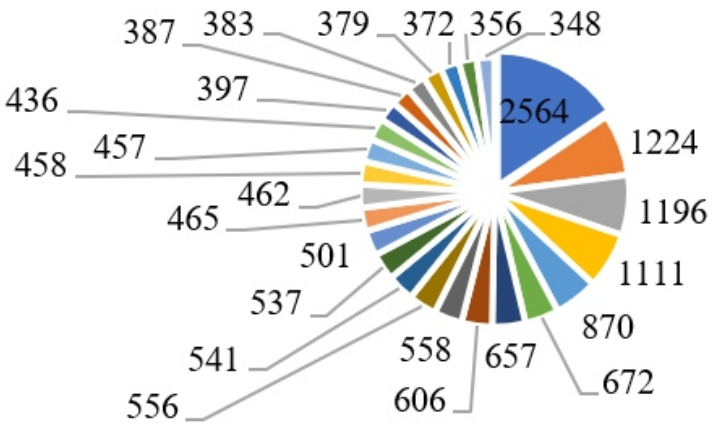

- radiation monitoring (2.564) - reactor accidents (1.224) " radioisotopes (1.196)

- cesium isotopes (1.111) - nuclear power plants (870) " radioactivity (672)

- spectroscopy (657)

- pollution (606)

- radiation dose (556)

- humans (541)

- gamma radiation $* 558)$

- cesium 137 (501)

- chemistry (465)

- radon isotopes (537)

- pollutants (458)

- radiation exposure (457)

- air pollution (462)

- atmospherics (397)

- environment (387)

- contamination (436)

- fallouts (379)

- radioactive wastes (372)

- uranium isotopes (383)

- theoretical model (348)

- concentration (356)

Gambar 4. Peringkat 25 kata kunci setelah dicocokkan dengan thesaurus INIS 


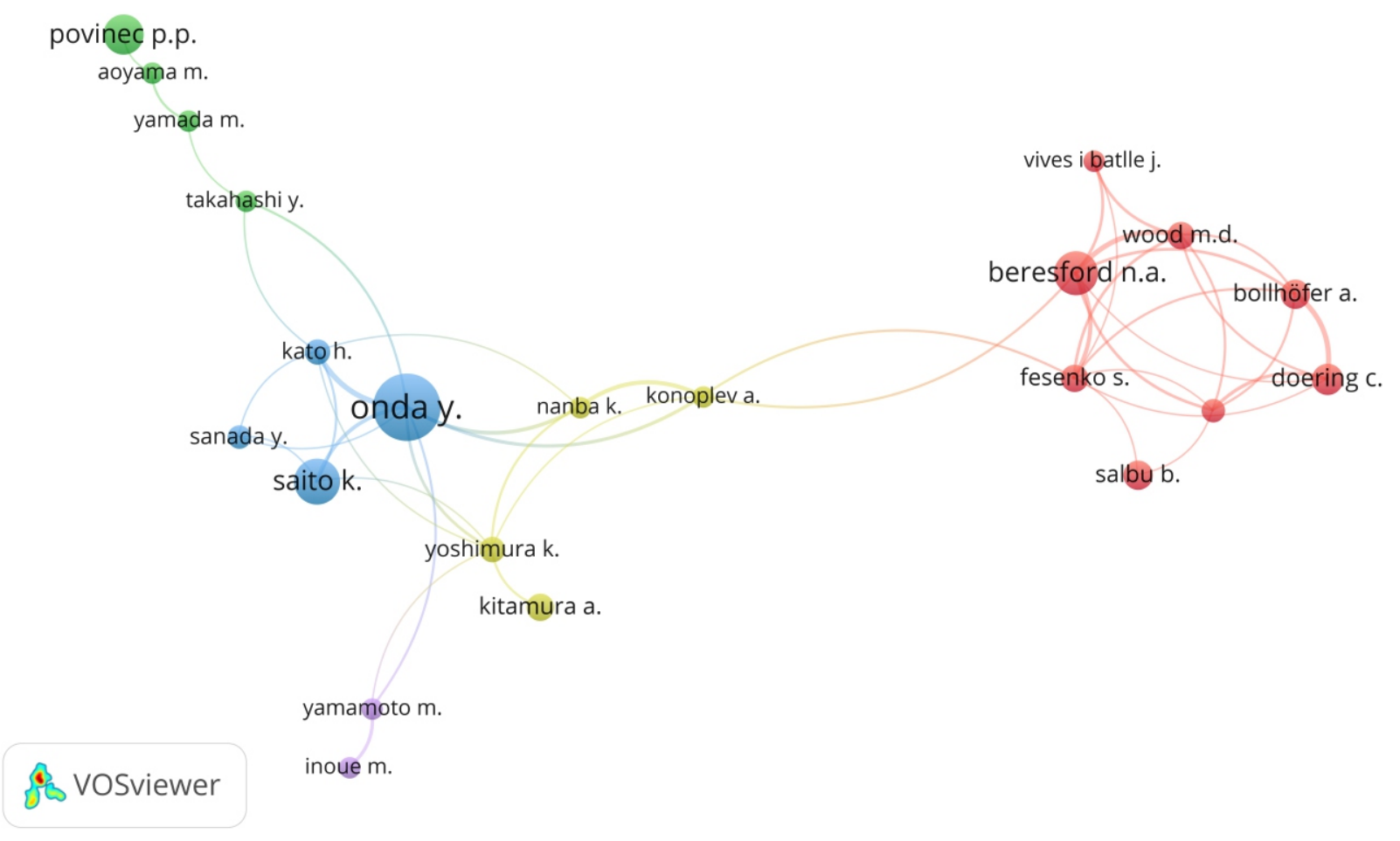

Gambar 5. Pemetaan penulis kolaborasi penulis (co-authorship) bidang pemantauan radiasi dengan kriteria minimal 10 dokumen dan disitasi 100 kali

DAFTAR TABEL

Tabel 1. Peringkat 10 besar peneliti yang paling produktif di bidang pemantauan radiasi pada scopus Tahun 2011-2019

\begin{tabular}{llccc}
\hline \multicolumn{1}{c}{ Peneliti } & \multicolumn{1}{c}{ Institusi } & Jumlah & Jumlah \\
Publikasi & Sitasi & h-Index \\
\hline Onda, Y. & University of Tsukuba, Japan & 35 & 1.140 & 37 \\
Beresford, N.A. & University of Salford, Salford, United Kingdom & 23 & 373 & 34 \\
Povinec, P.P. & Comenius University, Bratislava, Slovakia & 20 & 361 & 43 \\
Saito, K. & Japan Atomic Energy Agency, Kashiwa, Japan & 20 & 512 & 20 \\
Eslinger, P.W. & Pacific Northwest National Laboratory, Richland, United States & 17 & 265 & 9 \\
Kovács, T. & Pannon Egyetem, Veszprem, Hungary & 17 & 106 & 19 \\
Bowyer, T.W. & Pacific Northwest National Laboratory, Richland, United States & 15 & 326 & 19 \\
Doering, C. & Australian Government, Department of the Environment, Australia & 15 & 139 & 8 \\
Miley, H.S. & Pacific Northwest National Laboratory, Richland, United States & 15 & 259 & 34 \\
Salbu, B. & Universitetet for Miljø- og biovitenskap, As, Norway & 15 & 160 & 37 \\
\hline
\end{tabular}

Sumber: Data primer yang diolah (Noeraida, 2020) 